Zabytkoznawstwo i Konserwatorstwo XLIII, Toruń 2012

Justyna Olszewska-Świetlik*, N. Gruszczyk***

* Zakład Technologii i Technik Malarskich, Wydział Sztuk Pięknych UMK

** Muzeum Górnośląskie w Bytomiu

\title{
Technologia i technika malarska wybranych temper kazeinowych w malarstwie sztalugowym
}

\section{Zarys historii stosowania spoiw kazeinowych}

\ ne jest od czasów prehistorycznych. W historycznych źródłach pisanych kazeina wymieniana jest głównie w kontekście bardzo silnych klejów do drewna lub jako spoiwo farb w malarstwie ściennym ${ }^{1}$. Literatura przedmiotu najczęściej ogranicza się do opisania techniki jako tempera, bez głębszej konkretyzacji. Spoiwo kazeinowe mogło być wykorzystywane w zaprawie i warstwie malarskiej w obrazach sztalugowych na desce i płótnie ${ }^{2}$. Historia stosowania temper kazeinowych w malarstwie sztalugowym zaczyna się później niż w malarstwie ściennym. Na podstawie rachunków znalezionych w archiwum katedry w Treviso (północne Włochy) pochodzących z 1520 i 1521 wiemy, że kleje kazeinowe stosowane były do gruntowania podobrazi drewnianych. Potwier-

1 Patrz na przykład: Manuskrypt z. Lukke, IX wiek, [za:] G. A. Berger, Quellen und Techniken der Fresco-Oel- und Tempera- Malerei des Mittlealtes, München 1912, 2 Aufl., Reprint Waluff 1973, s. 17; Teofil Prezbiter, Diversarum artium schedula, Średniowieczny zbiór przepisów o sztukach rozmaitych, przekład i opracowanie St. Kobielus, Kraków 1998, s. 15; C. Cennini, Rzecz o malarstwie. Teksty źródtowe do džejón teorii sztuki, t. 3, red. J. Starzyński, Wrocław 1955, s. 61.

2 Z. Brochwicz, Toruński portret Kopernika w swietle nowych badań technologicznych, Rocznik Muzeum w Toruniu, t. 5, Toruń 1973, s. 120. 
dzeniem stosowania tempery kazeinowej w średniowiecznym malarstwie tablicowym jest między innymi przedstawienie Chrystus Umęzony na drzwiczkach sakrarium z kościoła p.w. św. Piotra i Pawła w Mariance Pasłęckiej, wykonany na początku XV wieku ${ }^{3}$ Nieco późniejszym przykładami dzieł, w których zidentyfikowano emulsyjne spoiwo kazeinowo-olejne w warstwie malarskiej, są obrazy gdańskiego warsztatu malarskiego drugiej połowy XV wieku ${ }^{4}$ Spoiwa kazeinowe, zidentyfikowano również w dziełach pochodzących z pierwszego dwudziestolecia XVI wieku . Kleju kazeinowego z dodatkiem jajka i oleju używał do malowania między innymi słynny wenecki artysta Tycjan (ok. 1589_

3 Sakrarium to polichromowana szafka o wymiarach $108 \times 80 \times 40 \mathrm{~cm}$, wykonana z dębowych desek o grubości od 3,5 do $4 \mathrm{~cm}$, z żeliwną kratą oraz drzwiczkami, które od strony wewnętrznej zdobi wspomniane przedstawienie. Obiekt pełnił funkcję tabernakulum. Badania mikroskopowe i mikrochemiczne spoiwa wykazały, że przedstawienie zostało namalowane na zaprawie kredowo-klejowej, farbą o chudym spoiwie kazeinowoolejnym $(\mathrm{o} / \mathrm{w})$, natomiast wnętrze sakrarium malowano monochromatycznie bezpośrednio na desce poprzez naniesienie dwóch warstw farby o tłustym spoiwie olejno-kazeinowym (w/o). Sakrarium z przedstawieniem malarskim Chrystusa Umeczonego było obiektem dyplomowym nr 1436 poddanym konserwacji i restauracji w Zakładzie Konserwacji Malarstwa i Rzeźby Polichromowanej UMK w Toruniu, prace wykonała Natalia Gruszczyk (Markunas) pod kierunkiem prof. Dariusza Markowskiego oraz dr Joanny Arszyńskiej. Badania budowy technicznej i identyfikacje materiałów wraz z dokumentacją wykonała Natalia Gruszczyk (Markunas) pod kierunkiem dr hab. Justyny Olszewskiej-Świetlik prof. UMK oraz mgr Małgorzaty Górzyńskiej, badania historyczno-artystyczne wykonała Natalia Gruszczyk (Markunas) pod kierunkiem dr hab. Jacka Tylickiego, prof. UMK, analiza XRF pigmentów - mgr Adam Cupa, chromatografia gazowa spoiw - mgr Grzegorz Jaworski, wykonanie i analiza zdjęć stratygrafii próbek w UV - dr Zuzanna Rozłucka, badania dendrochronologiczne - prof. Tomasz Ważny, konsultacje mikrobiologiczne - dr Joanna Karbowska-Berent.

4 Dzieła, w których zidentyfikowano spoiwo kazeinowo-olejne w warstwie malarskiej sa to: Obraz Chrystusa Zbawiciela, 1478-1482 (nr kat. 9, s. 119), Retabulum ze sw. Barbara, 1480 r. (nr kat. 11, s. 135), Predella ₹ Biczowaniem i cierniem koronowaniem, po 1484 r. (nr kat. 13, s. 152), za: J. Olszewska-Świetlik, Technologia i technika gdańskiego malarstwa tablicowego drugiej połony XV wieku, Toruń 2005.

5 Na przykład w obrazach weneckiego malarza Cariani (1490-1547), zidentyfikowano spoiwa temperowe, w tym kazeinowe, jako izolacje warstw farb olejnych. Te innowacyjne rozwiązanie pozwalało nadać niezwykła gładkość powierzchni, co szczególnie chętnie wykorzystywano w partiach karnacji czy tła, za: G. Bastek, G. Janczarski, Serenissima: śniatto Weneji: dzieła mistrzón weneckich XIV-XVIII wieku ze z̧biorón Muz̨eum Narodowego w Warszawie w smietle nowych badań technologicznych, historycznych i prac konserwatorskich, Muzeum Narodowe, Warszawa 1999, s. 168. 
-1576) ${ }^{6}$. Uważa się jednak, że XV i XVI wieku emulsja kazeinowa była bardziej popularna w zachodniej i północnej Europie, zwłaszcza do wykonywania szarych - grisaillowych podmalowań7. Albrecht Dürer (1471-1528) w Pamietnikach ₹.podróýy po Niderlandach wspomina o używaniu boraksu. Fakt ten może świadczyć o tym, że malarz stosował ten materiał do rozklejania kazeiny, która mogła służyć do celów malarskich (spoiwo do zapraw i farb) ${ }^{8}$. W pochodzącym z 1520 roku antwerpskim retabulum zwanym śn. Adriana z Bazyliki Mariackiej w Gdańsku zidentyfikowano spoiwo kazeinowe w zaprawie i spoiwie malarskim?. Artyści antwerpskiego warsztatu malarskiego wykonali podmalowanie tłusta, emulsyjną farba kazeinowo-olejną na zaprawie kredowo-klejowej z izolacją olejną lub olejno-żywiczna, następnie kładli olejne, olejno-żywiczne oraz emulsyjne (również olejno-kazeinowe) warstwy ostatecznego opracowania malarskiego. Również wśród nowożytnych epitafiów drugiej połowy XVI i początku XVII wieku, znajdujących się w Bazylice Mariackiej w Gdańsku, odkryto spoiwo kazeinowe ${ }^{10}$. Dalsze badania dowodza, że w wieku XVII i XVIII tempera kazeinowa była stosowana także na podobraziach płóciennych. Przykładem sa portrety protestanckich duchownych wykonane przez artystów warsztatu gdańskiego. Zarówno w warstwie malarskiej jak i w zaprawie zidentyfikowano emulsje kazeinowo-olejne ${ }^{11}$.

6 Za: A. Targowska-Semeniuk, Próby zastosowania różnych temper kazeinonych do punktowania freskonych $i$ temperonych malowidet ściennych, praca magisterska pod kier. prof. dr Z. Brochwicza, Toruń 1983, s. 4.

7 J. Flik, Portret Mikołaja Kopernika. Studium warsztatu malarskiego, Toruń 1990, s. 68.

8 A. Targowska-Semeniuk, op. cit., s. 4; F. Decker, Historische Maltechnike und Kopie, Hochschule für Bildende Künste Dresden, Dresden 1983, s. 132.

9 Antwerpski warsztat malarski wykonal podmalowanie tłusta, emulsyjna farbą kazeinowo-olejną na zaprawie kredowo-klejowej z izolacją olejną lub olejno-żywiczną. Następnie wykonano dalszy modelunek przy użyciu bardziej „tłustego” spoiwa olejnego, olejno-żywicznego oraz emulsyjnego (olejno-kazeinowego) za: J. Olszewska-Świetlik, Warsætat malarski antwerpskiego retabulum św. Adriana ₹ Basyliki Mariackiej w Gdańsku, Wyd. Naukowe UMK, Toruń 2008, s. 21, 43.

10 Dziełami, w których zidentyfikowano kazeinę w warstwie podmalowania, są: Epitafium Georga Hojera, 1585 r. (nr kat. 3, s. 62), Epitafium Jacobsa Schadiusa, 1588 r. (nr kat. 4, s. 73), Epitafium Hansa Gronau, 1612 r. (nr kat. 5, s. 88). Por. tab. 1, s. 103-104 za: J. Olszewska-Świetlik, Technologia i technika malarstwa mybranych nowosytnych epitafiów z Basyliki Mariackiej w Gdańsku,Torun 2009.

11 Obrazami, w których zidentyfikowano kazeinę, olej lniany oraz żywicę naturalną w warstwie malarskiej są: Portret pastora Ephraima Kerstena, 1691 r. (nr kat. 1, s. 16), Portret 
W XIX wieku rozpoczęła się przemysłowa i komercyjna produkcja kazeiny, co wpłynęło na wzrost jej popularności. Od pierwszej połowy XIX wieku można było kupić suchy proszek kazeinowy ${ }^{12}$. Od drugiej połowy XIX wieku oraz w wieku XX, technika kazeinowa była odkrywana na nowo. Klej kazeinowy stosowano do wyrobu zapraw i farb malarskich. Technika tempery kazeinowej stała się ponownie nowa alternatywą dla używanych środków malarskich, z której chętnie korzystali eksperymentujący malarze $\mathrm{z}$ różnych środowisk.

Przykładem artysty tego okresu, który docenił zalety spoiwa kazeinowego, jest Edward Munch (1863-1944) - norweski malarz i grafik. W latach dziewięćdziesiątych szukał techniki oddającej wrażenie fresku na podobraziu płóciennym. Wykorzystał technikę kazeinowa, popularną wówczas w malarstwie ściennym w Bawarii i Tyrolu. W tej technice namalował w 1894 roku Portret polskiego pisarza Stanisława Praybylskiego ${ }^{13}$. Natomiast w polskim

Teophilusa Jungiusa, 1696 r. (nr kat. 2, s. 20), Portret pastora Daniela Schmidta, 1699 r. (nr kat. 3, s. 24), Portret pastora Michaela Ulmitza, 1706 (nr kat. 4, s. 29), Portret pastora Johanna Gotfrieda Kirscha, 1724 r. (nr kat. 5, s. 33), Portret pastora Joannesa Falcta, 1729 r. (nr kat. 6, s. 37), Portret pastora Johanna Beniamina Dragheima, 1761 r. (nr kat. 7, s. 41), Portret nieokreślonego pastora, po 2 poł. XVIII w. (nr kat. 8, s. 44). Kazeinę i olej lniany w różnych proporcjach zidentyfikowano w spoiwie zapraw wszystkich obrazów. Spoiwo o/w zidentyfikowano w dziełach o nr kat. 1, 2, 3, 8, natomiast spoiwo w/o w dziełach: 4, 5, 6, 7. Por. tab. 2, s. 101 oraz tab. 3, s. 102-103, [za:] J. Olszewska-Świetlik, Gdanski warsz̨at malarski schytku XVII i w XVIII wieku na prayktadach wybranych portretów przedstawiajacych protestanckich duchownych, Toruń 2010; idem, Zagadnienia warsztatu malarskiego Epitafium Hansa Gronau z. Basyliki Mariackiej w Gdańsku, Acta Universitatis Nicolai Copernici. Zabytkoznawstwo i Konserwatorstwo, t. XXXVIII, Toruń 2010, s. 129-142.

12 T. Brachert, Lexikon historischer Maltechniken, Callwey, München 2001, s. 134; G. A. Berger, Quellen und Techniken der Fresco- Oel- und Tempera- Malerei des Mittlealtes, München 1912, 2 Aufl., Reprint Waluff 1973, s. 17.

13 Munch wykonywał liczne eksperymenty, o których wspominał między innymi w korespondencji z malarzem Erikiem Warenskiold, który też przyznał się do stosowania zaprawy kazeinowej pod farby olejne. Munch malował temperą kazeinowa na zaprawie kazeinowej. Dziś nie można nazwać prób artysty jako w pełni udane. Zaprawa kazeinowa powoduje spękania warstwy malarskiej, a farba często pudruje się, jak na przykład w obrazie Akt siedz̨qy z 1893 roku. Powodem jest jednak nie tylko błąd w technologii i technice malarskiej ,ale przede wszystkim stosowane przez samego artystę eksperymenty polegające między innymi na wystawianiu obrazów na działanie niekorzystnych warunków atmosferycznych w celu uzyskania matowej powierzchni obrazów, za: H. Althöfer, Das 19. Jabrbundert und die Restaurierung. Betreige zur Malerei, Maltechnik und Konservierung, Callwey, München 1987, s. 112-121. 
malarstwie XIX wieku między innymi Aleksander Gierymski (1850-1901), stosował w swojej twórczości spoiwa kazeinowe ${ }^{14}$. Począwszy od przełomu XIX i XX wieku aż do dziś, technika tempery kazeinowej bywa stosowana przez artystów różnych nurtów sztuki, pochodzących z wielu zakątków świata, samodzielnie oraz $\mathrm{w}$ pracach o technice mieszanej $j^{15}$.

Jednym z amerykańskich artystów XX wieku, malującym temperami kazeinowymi jest malarz Jacob Lawrence (1917-2000), malował na kartonie lub papierze tempera jajkową i kazeinową w cienkich warstwach, uzyskując efekt podobny do gwaszu ${ }^{16}$. Znany jest również namalowany w 1932 ro-

14 Gierymski malował techniką olejną na kremowej zaprawie kazeinowej, którą uzyskano mieszając biel ołowiowa, biel barytowa i gips z emulsja z kleju glutynowego, kazeiny i oleju schnącego. Zaprawa naniesiona została w jednej warstwie, tworząc groszkową fakturę, prawdopodobnie przez nałożenie przy użyciu wałka lub gąbki. Faktura ta aktywnie uczestniczy w tworzeniu kompozycji malarskiej. Przeświecające przez warstwy farb chropowatości gruntu wzbogacaja fakturę obrazu i nadają lekkości kompozycji kolorystycznej. Przykładem zastosowania zaprawy kazeinowej jest obraz pt. Hamlet, [za:] E. Doleżyńska-Sewerniak, Materialy malarskie i technika w obrazach olejnych Aleksandra Gierymskiego, Torun 2010, s. 206; H. Althöfer, op. cit., 1987, s. 112-121.

$15 \mathrm{Na}$ początku XX wieku, pod wpływem rosnącego podziwu dla efektu i trwałości średniowiecznych malowideł, zachęceni traktatem Cennino Cenniniego artyści postanowili ożywić zapomnianą technikę malarstwa temperowego. W pierwszej kolejności skupiono się na temperze jajowej, lecz z czasem zwrócono uwage i na kazeinową. W pierwszej kolejności skupiono się na temperze jajowej, lecz z czasem zwrócono uwagę i na kazeinową. W Wielkiej Brytanii w 1901 roku Christiana Herringham założyła działające do 1907 roku Stowarzyszenie Malarzy Malujących Tempera (The Society of Painters in Tempera lub The Tempera Society). Stowarzyszenie wznowiło swoją działalność w 1997 roku w USA i Wielkiej Brytanii. Artyści oprócz zalet dostrzegali także wady dawnych technik, co stało się inspiracją do modyfikowania spoiw oraz tworzenia nowych temper.W Ameryce Pólnocnej popularność tempery kazeinowej była zapewniona dzięki produkcji kazeinowych farb w tubkach. W latach osiemdziesiątych XX wieku do spoiwa kazeinowego dodawano tak zwanych farb plakatowych. Dostępne w drugiej połowie XX wieku farby wodorozcieńczalne w tubach były to tempery, których spoiwo rzadko podawano na etykietach. Nie można wykluczyć obecności kazeiny w ich składzie, stąd część artystów malujących tempera produkowaną fabryczną mogła nawet nie wiedzieć, że maluje temperą kazeinową. Dziś również trudno jest dowiedzieć się jakie jest dokładne spoiwo temper w tubach, na etykietach nie zawsze znajduje się dokładny skład farby. za : http://www.eggtempera.com/index.html, z dnia 29.05.2010; A. P. Laurie, The Painter's Methods and Materials, Dover Publications, New York 1967, s. 174; H. Kühn, H. R. Rünge, R. E. Straub, M. Koller, Farmittel Buchmalarai Tafel- und Leinwandmalere, Philipp Reclam jun., Stuttgart 1984, s. 47.

$16 \mathrm{http} / /$ whitney.org/www/jacoblawrence/meet/index.html dnia 8.05.2011 r.; A. Sultan, Luminous Brush: Painting With Egg Tempera, Watson-Guptil Publications, New York 1999, s. 106. 
ku obraz Ad Parnassum, autorstwa Paula Klee (1879-1940), malarza szwajcarsko-niemieckiego. Dzieło namalowane zostało farbami kazeinowymi na tradycyjnym płótnie $z$ białą zaprawą ${ }^{17}$.

Tempera kazeinowa nadaje się nie tylko na podobrazie drewniane czy płócienne, co udowodnił Gregory D. Ivy (1904-1985) - amerykański malarz modernistyczny, malując w 1950 roku obraz Kamienie, muszle $i$ kości na płycie pilśniowej „masonit”"

Balthus (1908-2001) - polsko-francuski malarz łączący realizm z surrealizmem, szukał techniki pozwalającej uzyskać efekt fresku na płótnie - matowy z niewielkim połyskiem. Wykonywał różne próby, najbardziej odpowiadało mu caserarti, mieszanina kazeiny, gesso, gipsu z farbami olejnymi. Obraz Ćma z lat 1956-1960 malował na płótnie farbami z kazeiną mleczną, uzyskując pokrytą grudkami, matowa powierzchnię ${ }^{19}$.

Przykładem zastosowania zaprawy kazeinowej w malarstwie XX wieku jest olejny obraz Bathing z 1911 roku, który został namalowany przez Duncana Granta (1885-1978), brytyjskiego malarza, członka grupy Bloomsbury. Obraz namalowany jest na podobraziu płóciennym o rozmiarze 169x137 cm, z jasnoszara, prawdopodobnie popularną wówczas, produkowaną fabrycznie przez Case-Arte, zaprawą kazeinową ${ }^{20}$.

17 D. A. Anfam, M. Beal, E. Bowes i in., Techniki wielkich mistrón malarstwa, przeł. D. Stefańska-Szewczuk, M. Dolińska, B. Mierzejewska, Arkady, Warszawa 2006, s. 422.

18 http://weatherspoon.uncg.edu/exhibitions/show/?title=gregory-d-ivy-making-northcarolina-modern dnia 7.03.2011źr.

19 G. Berger, Unconventional treatments for unconventional paintings, Studies in conservations, 1976, nr 21, s. 115-128; http:/ / books.google.pl/books?id=-d16-nv66rkC\&pg=PA59\&lpg= PA59\&dq =balthus + casein\&source $=$ bl\&ots=Ax24B6B_7c\&sig=kj7q6uRwzQGriawTdLO4w KLjI2A\&hl=pl\&ei=lhl1TbyBMofOswbRpI2EDg\&sa=X\&oi=book_result\&ct=result\&resnu $\mathrm{m}=1$ \&ved=0CBYQ6AEwAA\# $\mathrm{v}=$ onepage $\& \mathrm{q}=$ balthus $\% 20$ casein\& $\mathrm{f}=$ false [za:] Gilles Néret, Balthasar Klossowski de Rola Balthus, 1908-2001: the king of cats, Taschen GmbH, Köln 2003, s. 59, 77; http://warszawa.gazeta.pl/warszawa/1,34861,2605750.html dnia 7.03.2011r.

20 Pod warstwą malarską znaleziono rysunek wykonany ołówkiem lub węglem drzewnym. W warstwie malarskiej zidentyfikowano olej lniany oraz makowy, często stosowany w połączeniu z jasnymi pigmentami z powodu mniejszego żółknięcia. Zidentyfikowano również niewielki dodatek wosku pszczelego, pochodzaccego prawdopodobnie z farb olejnych produkowanych fabrycznie, za: S. Hackney, R. Jones, Y. Townsend, Paint and Purpose. A study of technique in British art, Tate Gallery Publishing, London 1999, s. 110 . 
Techniki tempery kazeinowej wykorzystują również artyści współcześni. Jednym z nich jest malarz i grafik, mieszkający i pracujący w Łodzi - Stanisław Fijałkowski (urodzony w 1922 roku). Przykładowe prace, w których wykorzystał temperę kazeinowa, to: Siedem rapomnianych dobrych ucsynkón z 1969 roku - płótno o wymiarach 130x89 cm czy 2.II.63 z 1963 roku - płótno o wymiarach $21 \times 15,2 \mathrm{~cm}^{21}$.

Lech Kubiak, profesor w Zakładzie Technologii i Technik Malarskich, na toruńskim Wydziale Sztuk Pięknych Uniwersytetu Mikołaja Kopernika eksperymentuje ze spoiwami kazeinowymi ${ }^{22}$.

Podsumowując, można stwierdzić, że mimo unikatowego, matowego lub półmatowego charakteru, nie wykreował się żaden styl czy metoda malarska powiązana z kazeiną. Jest ona najczęściej alternatywą wśród innych spoiw w tym temperowych ${ }^{23}$.

\section{Otrzymywanie kleju kazeinowego}

Spoiwo kazeinowe, stosowane $\mathrm{w}$ malarstwie, otrzymuje się z kazeiny kwasowej - twarogu ${ }^{24}$. Aby otrzymać rozpuszczalny w wodzie roztwór o sile

21 http://www.artnewmedia.pl/pl/author/info/16akp8:HXGmkbIZqqpSurNDYV515a26aWmh2podso2ijZHicwtqmrcSkyp2JZnpdk6yT26Oco8NaaXFclH:IoNCmpF2Up1 xoqan Rqt6YnZnbi2Wn, z dnia 19.04.2010.

${ }^{22} \mathrm{~W}$ swoich olejnych obrazach od ponad trzydziestu lat posługuje się klejem kazeinowo-boraksowym, który przygotowuje i wykorzystuje w następujący sposób: „20 dag twarogu półtłustego lub chudego przecieram przez sito, aby go rozdrobnić. Rozpuszczam na ciepło 16 g boraksu w $100 \mathrm{ml}$ wody. Po złączeniu składników rozklejanie kazeiny następuje bardzo szybko. Najlepiej jest zostawić mieszaninę na drugi dzień, aby wszystkie grudki zostały rozklejone, lecz jeśli klej potrzebny jest od razu, można przetrzeć go przez sito. Aby stworzyć emulsję można łączyć klej z szybkoschnącym olejem gotowanym, lecz ja najczęściej dodaję 20\% lakieru olejnego. Przygotowuję go z oleju lnianego, werniksu damarowego i olejku terpentynowego w stosunku 1:1:1, najlepiej złączonych na ciepło. Podobnie mieszając składniki emulsji najlepiej jest je lekko ogrzewać. Gotowa emulsja zmienia barwę (nie jest już biała jak sam klej) i nabiera konsystencji śmietany. Można ja przechowywać około miesiąca, potem rozdziela się". Opisaną emulsję L. Kubiak wykorzystuje nie tylko do farb temperowych, ale i do gruntu emulsyjnego, aby zwiększyć jego chłonność. Relacja słowna L. Kubiaka.

23 J. Turner, The Dictionary of art., vol. 5, wyd. Grove, New York 1998, s. 912.

24 W. Ślesiński, Techniki malarskie. Spoiwa organiczne, Warszawa 1984, s. 91. 
klejącej, należy rozetrzeć twaróg, wielokrotnie przepłukać w wodzie, a następnie odkwasić rozpuszczając w roztworze związku alkalicznego. Spoiwo kazeinowe stosowane do celów malarskich można otrzymać poprzez łączenie kazeiny z:

- wapnem gaszonym $\mathrm{Ca}(\mathrm{OH})_{2}$ - otrzymując kazeinę wapienną (tworzy błony nierozpuszczalne po wyschnięciu);

- boraksem $\mathrm{Na}_{2} \mathrm{~B}_{4} \mathrm{O}_{7} \cdot 10 \mathrm{H}_{2} \mathrm{O}$ - otrzymując kazeinę boraksową (tworzy błony rozpuszczalne po wyschnięciu);

- amoniakiem $\mathrm{NH}_{3}$ lub węglan amonu $\mathrm{NH}_{4} \mathrm{HCO}_{3}$ - otrzymując kazeina amoniakalną (tworzy błony rozpuszczalne po wyschnięciu).

Wybranym przepisem na otrzymywanie kleju kazeinowego, który został zrealizowany w ramach wykonywanych prób jest:

- $1000 \mathrm{~g}$ sera chudego, świeżego,

- 150 g boraksu w 0,5 litra wody (roztwór 15\%).

„Do sera przetartego przez sito wsypuje się boraks, zalewa $500 \mathrm{~g}$ wody. Po kilku godzinach tworzy się jednolita masa [...]"25.

\section{Zaprawy kazeinowe}

Jednym z elementów badań było wykonanie zapraw kazeinowych. Do realizacji wybrano jedna zaprawę klejową oraz jedną emulsyjną.

Klejową zaprawę kazeinową wykonano w następujący sposób ${ }^{26}$ :

- 2 części objętościowych kredy (uprzednio utartej w moździerzu z niewielką ilością wody),

- 2 części objętościowych wody,

- 1 części objętościowej kleju kazeinowego.

Składniki w przedstawionych proporcjach dały substancję o rzadkiej konsystencji, którą łatwo nanosiło się pędzlem, tworząc bardzo cienkie

25 J. Flik, op. cit., s. 68.

26 Bazą do wykonania zaprawy kazeinowej był przepis wg Dornera: [...] gruntowanie: 1 część naturalnego gipsu,1 część bieli cynkowej („,czerwona pieczęć”) miesza się z 2 częściami wody aż do otrzymania bezgrudkowej papki, po czym domieszać: 1 część nierozcieńczonego roztworu kazeiny za: M. Doerner, Materialy malarskie $i$ ich zastosowanie, Warszawa 1975, s. 31. 
warstwy. W efekcie uzyskano gładkie powierzchnie zaprawy, wymagajace miejscowego, delikatnego wygładzenia papierem ściernym jedynie tam, gdzie pozostał płytki ślad duktu pędzla lub nieroztarte aglomeraty pigmentu. Zaprawa była miękka i bardzo łatwo poddawała się szlifowaniu, dając efekt gładkiej, matowej powierzchni zarówno na sklejce, jak i na płótnie. W porównaniu z zaprawą kredowo-klejową cechowała się niezwykłą świetlistością bieli. Po tygodniu stała się odporna na wodę. Jej wadą była trudność w uzyskaniu grubszej warstwy zaprawy, przydatnej przy opracowaniu wklęsłego grawerunku pod opracowanie pozłot. Na podobraziu płóciennym zaprawa ujawniła swoją kruchość i niewielką elastyczność, lecz w ciagu trzech miesięcy od naniesienia nie zauważono, aby pudrowała się lub kruszyła, jedynie przy mocnym wyginaniu płótna pojawiały się mikrospękania.

Emulsyjną zaprawę kazeinową wykonano w pięciu wariantach, modyfikując zawartość oleju w stosunku do kleju kazeinowego (mierzone objętościowo: I. 5\%: 0,5 części oleju + 9,5 części kleju kazeinowego, II. 10\%: 1 części oleju + 9 części kleju kazeinowego, III. 20\%: 2 części oleju + 8 części kleju kazeinowego, IV. 30\%: 3części oleju +7 części kleju kazeinowego, V. 40\%: 4 części oleju +6 części kleju kazeinowego) (tab.1)

Ostatecznie użyto zaprawy wykonanej zgodnie z wariantem 2, tzn.:

- 10 części objętościowych kredy,

- 1 część objętościowa oleju,

- 9 części objętościowych kleju kazeinowego.

Składniki należy wymieszać na zimno, gdyż pod wpływem ciepła zaprawa szybko gęstnieje, co utrudnia jej nakładanie.

W trakcie wykonywania prób początkowo stwierdzono, że zadowalajace efekty dała również zaprawa w wariancie 1 (0,5 części oleju $+9,5$ części kleju kazeinowego). Jednakże, chociaż zmiany barwne były niewielkie, po wyschnięciu zaprawa okazała się zbyt krucha - przy czterech warstwach pekała nawet przy delikatny wygięciu płótna. Zaprawa w wariantach 3, 4 i 5 z czasem bardzo pożółkła oraz, szczególnie przy czterech warstwach, popękała. Wymagane warunki najlepiej spełniała zaprawa w wariancie 2. Podsumowując, mimo dobrej elastyczności, nawet na podobraziu płóciennym, zaprawa nie może być polecana do celów malarskich z powodu żółknięcia, nawet przy minimalnej zawartości oleju, jak w wariancie 1. Wykorzysta- 
nie emulsyjnej zaprawy kazeinowej wymagałoby wykonania prób z innym wypełniaczem.

\section{Metodyka badawcza}

Celem pracy było możliwie najszersze zbadanie możliwości malarskich tempery kazeinowej poprzez zróżnicowane eksperymenty malarskie. Wykonano próby malarskie na dwóch typach podobrazia: sztywnym - drewnianym i elastycznym - płóciennym. Analizowano możliwości malowania na podobraziach bez zaprawy jedynie przeklejonych klejem glutynowym oraz z dwoma typami zapraw: klejową i emulsyjna. Dodatkowo położono kazeinową imprimiturę oraz izolacje olejno-żywiczną. Uzyskano zróżnicowane powierzchnie podobrazi. Końcowy schemat wykonywania prób na obu podobraziach, przedstawiono na ilustracji 1.

Badano cztery różne emulsje, tworząc:

1. temperę chuda na bazie emulsji typu olej w wodzie (o/w ) - 1. cz. obj. oleju lnianego, 3 cz. obj. kleju kazeinowego,

2. tempera tłustą na bazie emulsji woda w oleju (w/o) - 1. cz. obj. oleju lnianego, $1 \mathrm{cz}$. obj. kleju kazeinowego,

3. temperę modyfikowaną I (emulsja typu olej w wodzie $(\mathrm{o} / \mathrm{w})$ modyfikowana żółtkiem jaja) - 1. cz. obj. oleju lnianego, 3 cz. obj. kleju kazeinowego, 1 żółtko,

4. temperę modyfikowana II (emulsja typu olej w wodzie (o/w) modyfikowana terpentyna wenecka) $-3 \mathrm{cz}$. obj. kleju kazeinowego, 3/4 cz. obj. oleju lnianego, $1 / 4 \mathrm{cz}$. obj. terpentyny weneckiej w olejku terpentynowym (3:1).

Starając się uzyskać szerokie spectrum różnych możliwości opracowań malarskich stosowano trzy techniki malarskie:

- malarstwo kryjące plama,

- malarstwo laserunkowe,

- szrafowanie.

Malowano pigmentami polecanymi zarówno do malarstwa kryjącego, jak i laserunkowego, o średniej wielkości ziarna: umbra paloną, malachitem naturalnym, czerwienią żelazowa. 
Na podstawie oceny wizualnej analizowano możliwości malowania wybranymi temperami (tab. 2). Badano następujące parametry:

- łatwości malowania,

- czasu schnięcia,

- możliwości malarstwa impastowego,

- szczelności warstw temperowych,

- odporności warstwy malarskiej na olejek terpentynowy i wodę,

— elastyczności na podobraziach płóciennych.

\section{Badanie właściwości wybranych temper}

Trzy różne sposoby nakładania farb na zróżnicowanych podłożach pozwoliły na określenie łatwości malowania poszczególnymi temperami. Brano tu pod uwage przyczepność farb do podłoża, możliwość miękkiego modelunku i rysowania detali, konsystencję farby (czy nie „staje” pod pędzlem, czy się nie grudkuje), laserunkowość i siłę krycia. Są to pojęcia względne, stąd starano się spojrzeć na temat nieco szerzej. Nie tylko stwierdzano na przykład fakt transparentności lub siły krycia farb, lecz także oceniano sposób, w jaki farba się rozprowadza, czy na przykład pozostawia smugi czy też nie. Obserwacje podsumowano:

\section{Chuda tempera kazeinowo-olejna (il. 3)}

- chuda tempera kazeinowo-olejna schła bardzo szybko, bez względu na rodzaj podłoża i stopnia rozcieńczenia,

- farba jaśniała po wyschnięciu,

- najbardziej odpowiednią techniką dla chudej tempery kazeinowo-olejnej jest szrafowanie,

- laserunkowo na podobraziach bez zaprawy najlepiej malowało się na izolacji olejno-żywicznej, najgorzej natomiast na imprimaturze z izolacja,

— na zaprawie kredowo-klejowej najlepiej laseruje się na izolacji olejnożywicznej

- na zaprawie kazeinowej najlepiej laseruje się na imprimaturze kazeinowej,

- dwie warstwy zaprawy kazeinowej na płótnie nie pozwalaja na równomierne rozprowadzenie laserunku, gdyż farba zbiera się w zagłębieniach płótna, 
- malarstwo kryjące plama pozwalało na uzyskanie równomiernej powierzchni na każdym z podłoży, jedynie na najbardziej śliskiej i szczelnej zaprawie emulsyjnej wymagało kilku warstw tempery,

— w celu uzyskania ostrych kresek należy przygotować podłoże z zaprawa bez izolacji.

\section{Tłusta tempera kazeinowo-olejna (il. 4)}

- tłusta tempera kazeinowo-olejna, niezależnie od stopnia rozcieńczenia, po naniesieniu na podobrazie zastygała w ciagu kilku sekund, lecz z powodu dużej zawartości oleju w spoiwie, zmieniała swoja barwę jeszcze przez kilkanaście godzin,

- tłusta tempera nawet po rozcieńczeniu woda zastygała szybko, farba zaschnięta na palecie nie poddawała się już rozcieńczeniu,

- temperę należało przechowywać w zamkniętym naczyniu, a na paletę nakładać niewielkie porcje farby,

- niemożliwe było laserowanie na desce bez zaprawy lub z zaprawą kredowo-klejowa pokrytymi jednocześnie barwną imprimaturą i izolacja olejno-żywiczna,

- duża chłonność zaprawy kazeinowej utrudniała uzyskanie gładkiej, równomiernej laserunkowej plamy barwnej,

- szrafowanie na każdym z podobrazi było bardzo trudne, z uwagi na gęstość i szybkie zastyganie farby; pomagało obniżenie chłonności podłoża poprzez naniesienie izolacji olejno-żywicznej,

- najlepszym podłożem dla szrafowania tłusta tempera była zaprawa emulsyjna, choć i tu trudno było uzyskać delikatną kreskę,

— w malarstwie kryjącym najlepsze były podłoża bez izolacji olejno-żywicznej, która, z powodu ślizgania się pędzla i farby, bardziej sprzyjała laserunkom,

- tłusta tempera nanoszona kryjąco na podobrazie drewniane bez zaprawy pozostawiła wyraźne ślady pędzla,

- tłusta tempera w malarstwie kryjącym na płótnie bez zaprawy daje lepsze efekty niż tempera chuda.

\section{Modyfikowana tempera kazeinowa I (z żółtkiem jaja) (i1. 5, 6)}

- tempera modyfikowana I, podobnie jak tempera tłusta, była rozcieńczana woda, lecz bardzo szybko zastygała na palecie stając się żółtawa i trudna do rozpuszczenia, 
- dała bardziej intensywne barwy niż tempera chuda,

- malarstwu laserunkowemu sprzyjała izolacja olejno-żywiczna, przy malarstwie kryjacym wymagała kilku warstw farby,

- chłonność zapraw na desce utrudniała uzyskanie równomiernego laserunku,

- podłożem bardziej odpowiednim dla laserunków było płótno, szczególnie z warstwa imprimatur,

- szrafowanie na desce z zaprawa dało zadowalające efekty, lepsze niż tempera tłusta, lecz gorsze niż tempera chuda,

- imprimatura sprzyjała szrafowaniu na desce, w przeciwieństwie do izolacji olejno-żywicznej, która utrudniała uzyskanie ostrych kreseczek,

— na płótnie jedynym odpowiednim podłożem do malowania detali tempera była zaprawa kazeinowa, brak zaprawy oraz zaprawa emulsyjna sprzyjały perleniu się farby,

- malarstwo kryjące było najbardziej odpowiednią technika dla chudej tempery modyfikowanej żółtkiem jaja.

4. Modyfikowana tempera kazeinowa II (z terpentyną wenecka) (il. 7, 8)

- tempera modyfikowana terpentyną wenecka w olejku terpentynowym była rozcieńczana woda, szybko zastygała na palecie,

- najlepszą techniką dla tej tempery jest laserowanie, rozcieńczona farba dała równomierne laserunki, jedynie na zaprawie kazeinowej na desce pojawiły się delikatne plamy,

- najgorszym podłożem do szrafowanie była każdorazowo imprimitura z izolacją oraz płótno z zaprawą emulsyjna,

najlepszym podłożem dla szrafowania były zaprawy kredowo-klejowa i kazeinowa,

- szybkie wysychanie tempery utrudniało kryjące, równomierne pokrycie większej płaszczyzny,

- modelowanie tempera nie sprawiało trudności na żadnym z podłoży. Niektóre z badanych farb temperowych nadawały się nie tylko do malarstwa gładkiego, lecz również do nanoszenie grubszych, impastowych warstw. Poniżej zestawiono fotografie ukazujące możliwości uzyskiwania impastów badanych temper (tab. 3). 
Najlepsza do wykonywania impastów okazała się tempera 4 (modyfikowana I - z terpentyną wenecka), ponieważ pozwalała na nałożenie wysokich warstw farby bez względu na rodzaj podłoża. Pasta była na tyle gęsta, że nie zmieniała swojego kształtu w trakcie schnięcia. Podobne właściwości cechowały temperę 3 (tłusta tempera olejno-kazeinowa), lecz tu należało poczekać dłużej na wyschnięcie impastu - około godziny. Pozostałe tempery przy nałożeniu grubej warstwy rozpływały się, pozostawiając jedynie grubsza, bezkształtną linię farby.

Rodzaj podłoża nie miał wspływu na budowanie impastu. Dopiero po wyschnięciu uwidoczniała się tendencja do kruchości grubszych warstw tempery, lecz jedynie na podobraziach płóciennych. Najbardziej elastyczna była tempera tłusta ( $\mathrm{nr}$ 2), natomiast najmniej tempera modyfikowana żółtkiem jaja (nr 3).

Szczelność warstw temperowych badano poprzez próby na wsiąkania oleju. Wkraplano olej lniany na warstwę malarską oraz obserwowano szybkość jego chłonięcia aż do całkowitego zniknięcia. Wykonano badania po pięciu dobach od momentu malowania. Większa chłonność oleju wiąże się z mniejszą podatnością na laserowanie, gdyż powoduje to zmatowienie, utratę klarowności i czystości barwy.

Czas chłonięcia oleju przez warstwę temperową wahał się od 15 minut do 4,5 godziny. Najkrótszy czas zanotowano przy temperze nakładanej laserunkowo oraz metodą szrafowania na zaprawie emulsyjnej na podobraziu płóciennym. Najdłuższy czas cechował warstwy tempery 3 (modyfikowana I - z żółtkiem) kryjącej na zaprawie kredowo-klejowej na podobraziu drewnianym.

Próby wykazały, że bez względu na rodzaj podłoża i sposób malowania tempera kazeinowa 3 jest najmniej chłonna, co klasyfikuje ja jako najlepszą pod laserunki wśród badanych temper. Najbardziej chłonna, a więc najmniej odpowiednia do laserowania, okazała się tempera 4 (modyfikowana II - z terpentyną wenecka), przy której czas chłonięcia oleju nie przekraczał 1,5 godziny. Swój maksymalny czas uzyskała na podobraziu drewnianym na zaprawie kredowo-klejowej z izolacja.

Najmniej chłonnymi podłożami były: zaprawa kredowo-klejowa na desce oraz podobrazia bez zaprawy. Warstwa izolacji każdorazowa wpływała na wydłużenie czasu chłonięcia, szczególnie w połączeniu z imprimaturą. 
W celu sprawdzenia odporności temperowej warstwy malarskiej na wodę $\mathbf{i}$ olejek terpentynowy wykonano próby na desce $z$ zaprawą kazeinowa. Przy pierwszej próbie, 15 minut po naniesieniu farby, wszystkie tempery wykazały odporność na olejek terpentynowy. Tempera 1 i 2 po tygodniu stały się odporne na wodę, natomiast tempery 3 i 4 po 3 dniach.

Po pięciu dobach od namalowania sprawdzano elastyczność warstw temperowych na podobraziach płóciennych poprzez wygięcie płótna przez popchnięcie go od spodu palcem.

Na płótnie bez zaprawy najwyraźniejsze pęknięcia pojawiły się w warstwie tempery modyfikowanej żółtkiem jaja, lecz jedynie w partii impastu. Mikrospękania ujawnily się na warstwie każdej z temper malowanych kryjąco. Pozostałe sposoby malowania pozwoliły na tak niewielka grubość warstw, że nie pojawiły się żadne pęknięcia. Drugie podobrazie, gdzie malowano na zaprawie emulsyjnej, przy delikatnym wypchnięciu nie zmieniało się, lecz przy mocniejszym ruchu płótna ujawniało kruchość samej zaprawy, a w związku z tym również i cienkich warstw malarskich. Jedynie impast tempery 2 pozostał bez zmian. W przypadku zapraw kazeinowych pojawiły się różnice między zachowaniem podłoża z dwóch i trzech warstw zaprawy. Mniejsza liczba warstw dała podłoże dużo bardziej elastyczne, na którym jedynie wypchnięcie ostrzejszym przedmiotem powoduje wyraźne spękania. Przy trzech warstwach powierzchnia jest bardziej elastyczna tam, gdzie naniesiono izolację, zachowuje się ona podobnie jak zaprawa dwuwarstwowa.

Podsumowując, chociaż po kilku dniach od malowania temperowa warstwa malarska pozostała bez zmian na każdym z przygotowanych podobrazi, to na każdym z nich wypchnięcie płótna powodowało minimalne spękania. Jedynie w przypadku stosowania bardzo cienkich warstw farby nie przeszkadzała mała elastyczność tempery.

\section{Podsumowanie badań}

Obserwacja czterech wybranych temper kazeinowych na ośmiu podobraziach pozwoliła na określenie ich możliwości malarskich, natomiast zróżnicowanie podłoży ukazało jego wpływ na zachowanie się warstwy malarskiej. 
W pierwszej kolejności stwierdzono różnice pomiędzy poszczególnymi temperami. Chuda tempera kazeinowo-olejna (nr 1), zachowywała się podobnie do akwareli. Schła bardzo szybko, bez względu na rodzaj podłoża i stopień rozcieńczenia. Po 30 minutach uzyskiwała stałe nasycenie barw, stając się jaśniejszą niż po nałożeniu. Szczególną świetlistość barw zauważono na klejowej zaprawie kazeinowej. Przy gęściejszej farbie dawała powłokę kryjąca, lecz umożliwiała również mocne rozcieńczenie i malowanie laserunkowe. Laserunkom sprzyjała warstwa izolacji olejno-żywicznej lub imprimatury kazeinowej. Chuda tempera była to najlepsza wśród badanych farba do szrafowania, szczególnie na zaprawie bez izolacji olejno-żywicznej. Różnicując stopień rozcieńczenia, można było malować cienkimi kreseczkami o dowolnym stopniu krycia oraz pracować bardzo szybko poprzez nakładanie na siebie kolejnych warstw szybko wysychajacej farby. Ponadto pozwalała na wyrysowanie najdrobniejszych detali. Gęściejsza farba umożliwiała malarstwo kryjące plamą pozwalając na uzyskanie równomiernej powierzchni na każdym z podłoży, jedynie na najbardziej śliskiej i szczelnej kazeinowej zaprawie emulsyjnej wymagało to kilku warstw tempery. Przy badaniu możliwości kładzenia impastów dała jednak najgorsze rezultaty $\mathrm{z}$ wszystkich badanych temper, jak również w badaniu na chłonność charakteryzowała się jednym z gorszych wyników. Nie jest to więc najlepsza tempera do podmalowań pod laserunki olejne. Z drugiej strony warto zauważyć, iż tempera ta sama w sobie jest techniką bardzo wszechstronna. Pozwoliła nawet na malowanie na płótnie, choć trwałość takiej warstwy gwarantowało jedynie nanoszenie bardzo cienkich warstw farby, gdyż grubsza warstwa malarska łatwo pękała i kruszyła się. Ponadto po tygodniu warstwa chudej tempery na zaprawie jest całkowicie odporna na wodę i olejek terpentynowy.

Tłusta tempera olejno-kazeinowa okazała się najbardziej wymagająca wśród badanych farb, zarówno $z$ punktu widzenia technologii jak i techniki. Pierwszą wada były opisane w części badawczej trudności z przygotowaniem spoiwa, które wymagały prób lub doświadczenia i znajomości właściwości kleju kazeinowego i malarstwa temperowego. Natomiast główna wadą tempery z punktu widzenia techniki, była duża gęstość spoiwa. $Z$ jednej strony sugerowało to ciagłe rozcieńczanie farb w trakcie malowania, co powodowało jej większą przezroczystość, tymczasem jako farba oparta na 
spoiwie tłustym, była sama w sobie już laserunkowa. Chcąc uzyskać intensywne barwy, nie należało mocno rozcieńczać farby, co utrudniało malowanie detali, lecz pozwalało na malowanie plamą. Zaletą tempery był fakt, że mimo tłustej konsystencji rozcieńczała się w wodzie. Duża zawartość oleju powodowała zmianę barwy warstwy malarskiej przez około 48 godzin, aż do uzyskania jaśniejszego, ostatecznego koloru. Temperę cechowało mocniejsze $\mathrm{w}$ porównaniu $\mathrm{z}$ chudą temperą nasycenie barw po wyschnięciu, co stawało się widoczne szczególnie przy laserunkach. Jednakże laserowanie na desce bez zaprawy lub z zaprawą kredowo-klejowa pokrytymi jednocześnie imprimaturą i izolacją olejno-żywiczną było niemożliwe, farba perliła się. Natomiast na zaprawie kazeinowej duża chłonność podłoża utrudniała uzyskanie równomiernej palmy. Szrafowanie narzucało bardzo uważne rozcieńczanie farby, a i to pozwalało malować jedynie na zaprawie kazeinowej lub kredowo-klejowej, najlepiej o obniżonej chłonności poprzez warstwę izolacji olejno-żywicznej. Podłożem najbardziej odpowiednim do szrafowania tłusta temperą była kazeinowa zaprawa emulsyjna, choć i tu trudno było uzyskać delikatną kreseczkę. Swobodne malarstwo kryjące z możliwością budowania niewysokich impastów było utrudnione przez skłonność farby do laserunkowości, choć wykonane impasty były najbardziej elastyczne wśród badanych. W celu uzyskania większej, kryjącej plamy barwnej konieczne było nakładanie kilku warstw farby, najlepiej na podłoże bez izolacji olejno-żywicznej. Ponadto farbę cechowała niewiele mniejsza chłonność oleju w porównaniu z chudą tempera, podobnie nie jest to najlepsze podłoże dla olejnych laserunków. Warstwa tłustej tempery stała się odporna na olejek terpentynowy już po 15 minutach po namalowaniu, a na wodę po tygodniu.

Modyfikacja chudej tempery poprzez dodanie żółtka (nr 3) rzeczywiście polepszyła jej możliwości. Tempera wciąż była rozcieńczana woda, lecz bardzo szybko zastygała na palecie. Zdecydowanie poprawiło się nasycenie barw, lecz z czasem przybrało lekko źółtawego koloru. Najbardziej odpowiednią techniką dla chudej tempery modyfikowanej źółtkiem jaja było malarstwo kryjące. Farba pozwalała również na szrafowanie, choć trudniejsze było uzyskanie tak delikatnych kreseczek jak przy temperze chudej. $Z$ drugiej strony efekt był lepszy niz przy tłustej temperze. Modyfikowana żółtkiem chuda tempera miała tendencję do laserunkowości, szczególnie 
na izolacji olejno-żywicznej. Uzyskanie równomiernego laserunku utrudniała chłonność zapraw na desce, bardziej odpowiednim podłożem było tu płótno, szczególnie $z$ warstwą imprimatury. W przeciwieństwie do tempery tłustej, wystarczyła jedna, mniej rozcieńczona warstwa farby dla równego pokrycia większej powierzchni. Przy szrafowaniu najlepsze efekty uzyskiwano na imprimaturze kazeinowej na desce, natomiast na płótnie bez zaprawy oraz na zaprawie emulsyjnej zanotowano perlenie się farby. Ponadto jest to zdecydowanie najlepsza wśród badanych tempera do nakładania olejnych laserunków. Elastycznością nie odbiega od pozostałych badanych farb, natomiast szybciej niż tempera 1 i 2 staje się odporna na wodę - już po trzech dniach od namalowania.

Ostatnia badana farba była to chuda tempera kazeinowa modyfikowana terpentyną wenecką (nr 4). Sposób malowania przypominał temperę chuda, a więc przychodził z łatwością. Farby rozcieńczano woda. Pełne nasycenie barw jaśniejącej z czasem warstwy malarskiej uzyskano po upływie 12 godzin. Najbardziej odpowiednią techniką dla tej tempery było laserowanie. Farba pozwalała na równomierny modelunek, jedynie na zaprawie kazeinowej pojawiły się delikatne smugi. Możliwość szrafowanie uzależniona była od rodzaju powierzchni. Na zaprawie kazeinowej i kredowo-klejowej dawała zadawalające efekty, w przeciwieństwie do powierzchni z imprimaturą kazeinową i izolacją olejno-żywiczna, gdzie farba perliła się. Szybkie wysychanie tempery utrudniało równomierne, kryjące pokrycie większej powierzchni. Główna przewagą tempery modyfikowanej terpentyną wenecką nad temperą chudą była możliwość uzyskiwania wysokich, dowolnie ukształtowanych impastów przy użyciu nierozcieńczonej farby. Co więcej po pięciu dniach od naniesienia warstwy malarskiej na podobrazie płócienne, podczas wyginania podłoża, na warstwie malarskiej tworzyły się mikrospękania. Podobnie jak przy pozostałych temperach, w tej próbie najlepiej zachowały się cienkie warstwy malarskie. Ponadto tempera nr 4 najszybciej wśród badanych farb stała się odporna na wodę - już po 2 dniach.

Duży wpływ na zachowanie temper miał rodzaj podłoża. Najbardziej wymagające były podobrazia bez zaprawy. Deska z uwagi na mała chłonność i tworzenie tendencji do perlenia się farb, płótno ponadto $z$ uwagi na nierówna powierzchnię. Bardzo dużo zmieniała już jedna, cienka warstwa izolacji kazeinowej, która w niewielkim stopniu wyrównywała podłoże, oraz 
przede wszystkim poprawiała chłonność. Izolacja olejno-żywiczna najczęściej ułatwiała malowanie, ponieważ wyrównanie powierzchni umożliwiało już drobiazgowy modelunek czy szrafowanie. Jednakże farba rozprowadzała się podobnie, a więc gorzej niż na zagruntowanych podłożach. Wśród zapraw najgorszą była zaprawa emulsyjna, na której każda bardziej rozcieńczona farba ślizgała się. Przy szrafowaniu na poprawę właściwości wpływała izolacja olejno-żywiczna. Zaprawa kredowo-klejowa sprawdziła się dobrze w każdej technice, każdorazowo sprzyjając laserunkowości farb. Zaprawa kazeinowa, bez względu na liczbę warstw, dała powierzchnię o podobnym charakterze. Różniła się chłonnością, dając powierzchnię mniej odpowiednią dla laserunków, a przede wszystkim świetlistością, która nie zmieniała się z czasem, powodując świeżość i wyrazistość barw, szczególnie tych nanoszonych laserunkowo.

Izolacja olejno-żywiczna na każdym z podłoży wprowadzała tendencje do laserunkowości. Wadą izolacji był fakt, że z czasem zmieniała barwę, stając się ciemniejsza. Zmiana ta nie była widoczna na podobraziach bez zaprawy. Imprimatura kazeinowa była dobrym podłożem do malowania, zmienia charakter powierzchni w niewielkim stopniu, lecz trudno było ja idealnie równo nałożyć, szczególnie na większe powierzchnie.

Wykonane próby dowiodły, że temperą kazeinową można malować zarówno na podobraziu drewnianym jak i płóciennym. Należy jednak pamiętać, że płótno jest materiałem mniej stabilnym niż drewno, stąd ryzyko pękania grubszych warstw malarskich oraz impastów. Jednakże naniesiona laserunkowo na płótno tempera jest wystarczająco elastyczna. Charakterystyczną cechą jest tu wpływanie rzadkiej farby w splot płótna. Można zniwelować ten efekt poprzez dodanie warstw zaprawy lub naniesienie izolacji na przykład olejno-żywiczna.

W trakcie wykonywanych prób skupiono się na właściwościach spoiw, nie badając wpływu rodzaju pigmentu na temperę. Wybrano pigmenty reprezentujące uśrednione właściwości kryjące i laserunkowe. Poruszenie powyższego tematu wymagałoby szerszych prób i Wykonane badania moga stanowić wskazówkę dla osób chcących dowiedzieć się więcej na temat technik tempery kazeinowej. Jest to również źródło wskazówek dla chcacych malować techniką tempery kazeinowej, zarówno dla artystów, konserwatorów, jak i kopistów. Badane tempery moga służyć do uzupełnień 
warstw malarskich, szczególnie temperowych. Takie zastosowanie wymagałoby dalszych badań, szczególnie w zakresie odporności mikrobiologicznej, odwracalności i wpływu oleju na zmianę barwy tempery. Nie wyklucza się również zastosowania klejowych zapraw oraz farb kazeinowych w konserwacji, z uwagi na dobra odporność mikrobiologiczną oraz odporność na wodę.

\section{Summary}

\section{Technology and painting technique of chosen casein distemper in easel painting}

The aim of this article is to study some technology and technique of casein tempera aspects. Most information in former written sources refers to lime casein, which was used as a binder in wall painting or as a joiner's wood glue. Some already carried out research of the old painting technique indicates that beginning in the Middle Ages through the Renaissance and the Baroque, in the composition of binders casein could be identified. This fact proves that the importance of this binder in old painting was larger than known treatises and manuscripts reveal. The paper contains the results of some practical technology and technique studies of some selected, used in easel painting (on wood and on canvas), casein temperas. On the basis of that research, the way of the selected binders performance and their properties are presented. They can be used for artistic purposes as well as in the conservation and restoration work ${ }^{27}$.

27 The article is based on some authors' research, some of them is included in the N. Gruszczyk's master thesis, prepared under direction of dr hab. J. Olszewska-Świetlik, prof. UMK; Technoloqy and techniques of casein tempera in panel painting, Department of Painting Technologies and Techniques UMK, Toruń 2011. 

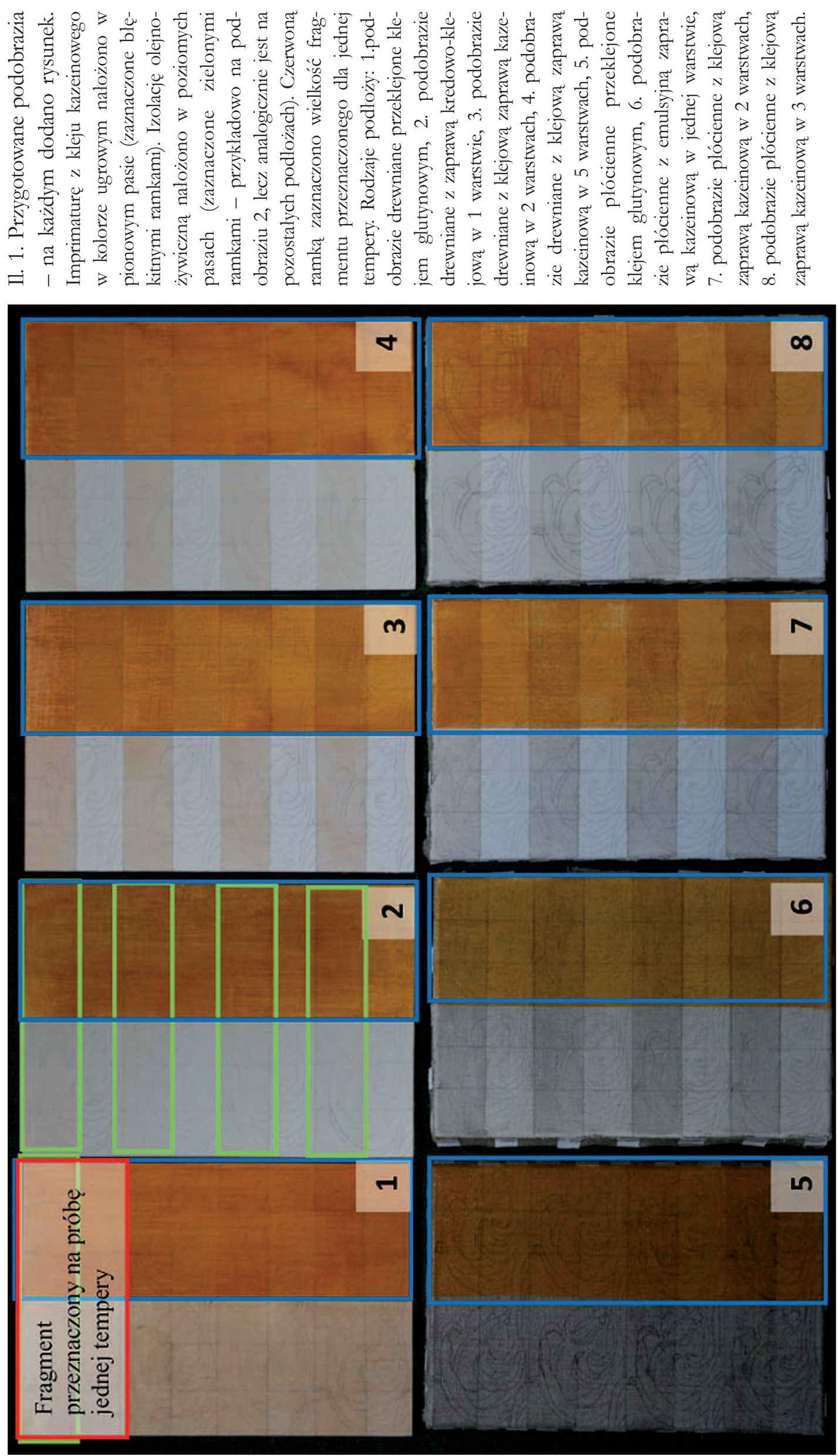


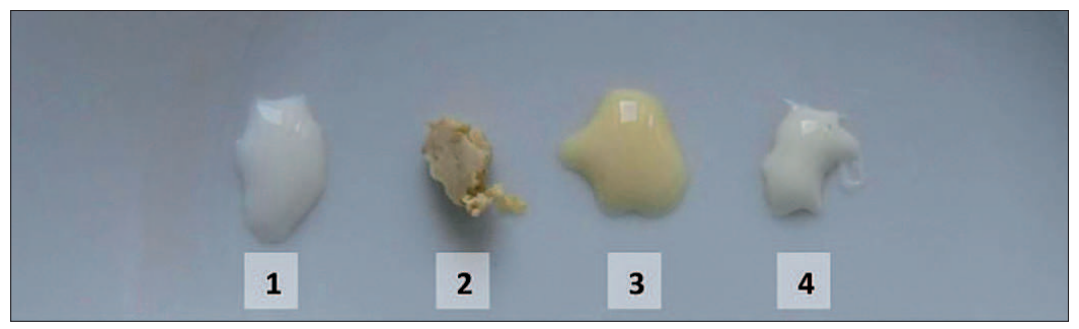

Il. 2. Porównanie barwy spoiw po 7 dniach od wykonania: 1. chuda emulsja kazeinowo-olejna, 2. tłusta emulsja olejno-kazeinowa, 3. emulsja kazeinowa modyfikowana I (chuda emulsja $z$ dodatkiem żółtka), 4. emulsja modyfikowana II (chuda emulsja z dodatkiem terpentyny weneckiej w olejku terpentynowym)

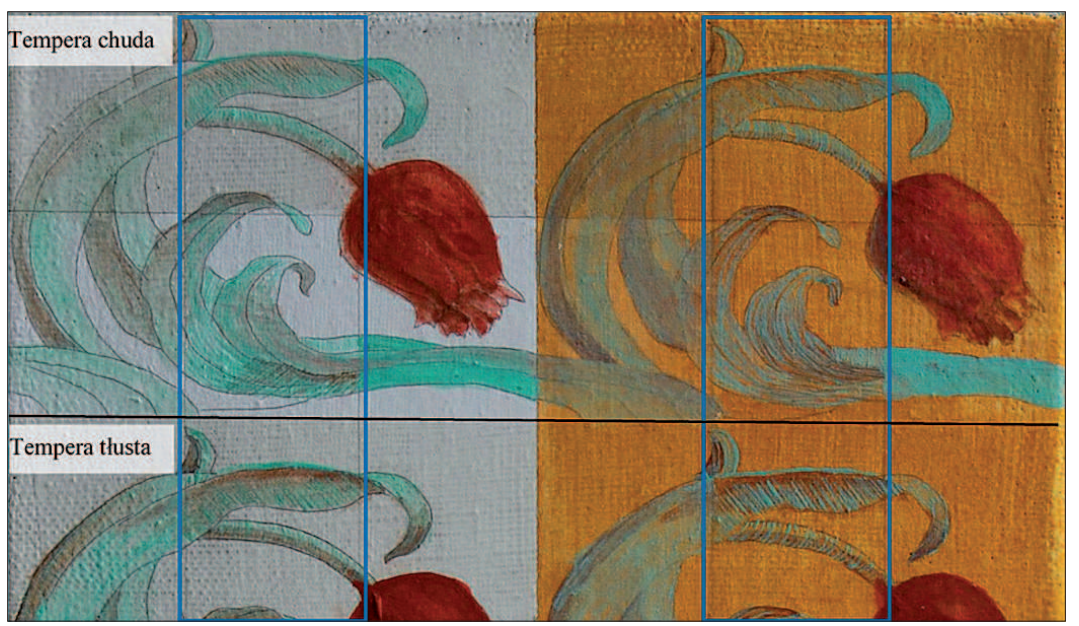

Il. 3. Porównanie prób na płótnie z zaprawą kazeinową w 3 warstwach, wykonanych temperą chuda (u góry) i tempery tłustej (u dołu). Różnice widoczne są szczególnie w pasie szrafowania - błękitne ramki. 


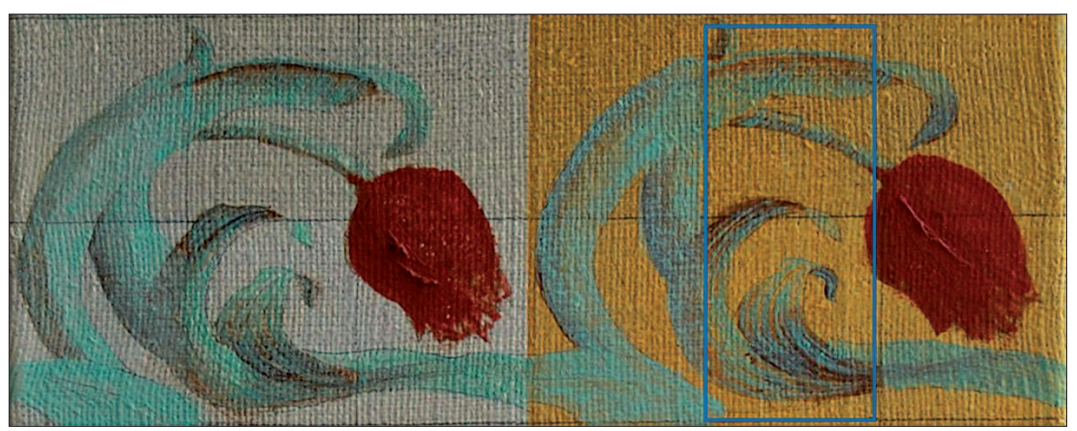

Il. 4. Tempera tłusta na płótnie z zaprawą emulsyjna. Gładkość i śliskość zaprawy pozwoliły na uzyskanie zadowalającego szafowania mimo gęstości tempery

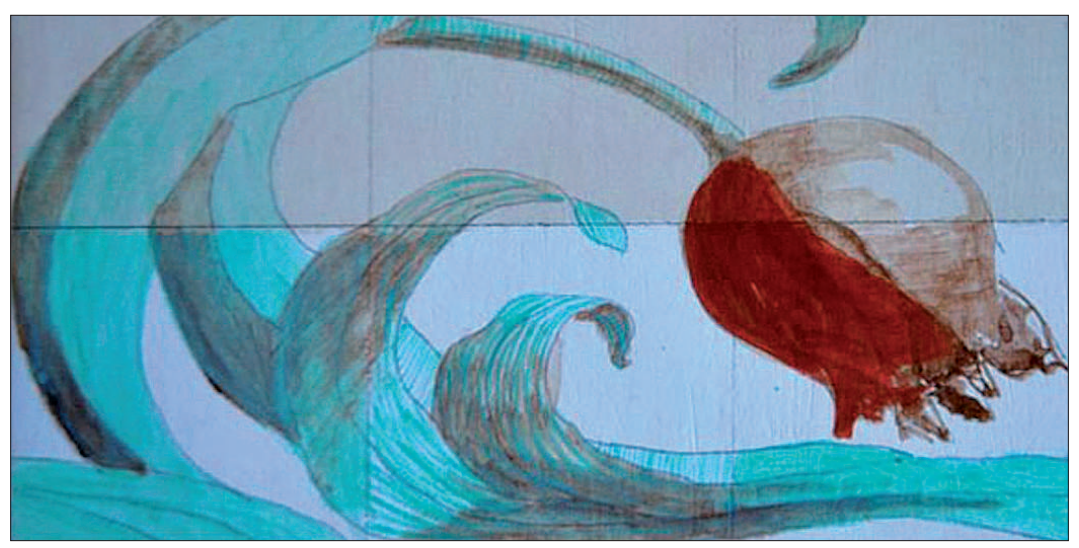

Il. 5. Fragment przedstawiający różnicę w przezroczystości czerwonej i zielonej tempery modyfikowanej I (modyfikowanej żółtkiem jaja) w zależności od obecności izolacji olejno-żywicznej (górny poziomy pas) na podobraziu drewnianym $z$ zaprawa kazeinowa $w$ pięciu warstwach.

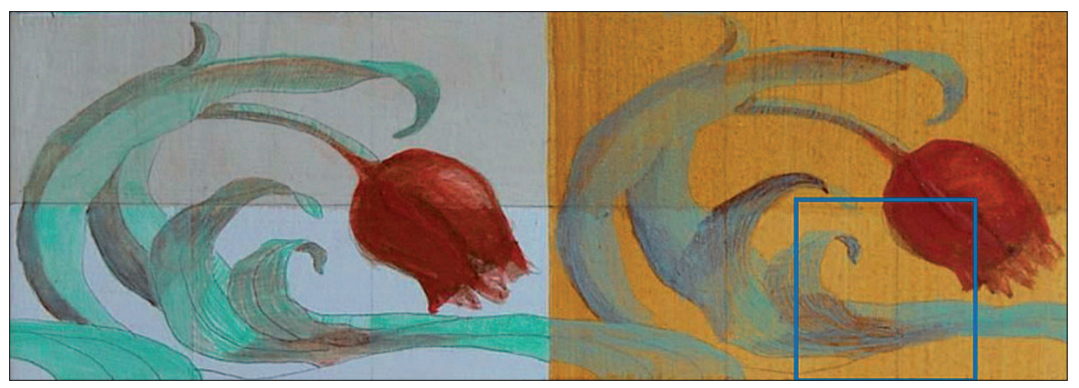

Il. 6. Tempera modyfikowana żółtkiem jaja na podobraziu drewnianym z klejowa zaprawa kazeinowa w 2 warstwach. Laserunki najbardziej równomierne sa na izolacji olejno-żywicznej (pas u góry), natomiast najdokładniejsze kreseczki szrafowania uzyskano na imprimaturze bez izolacji (ramka) 


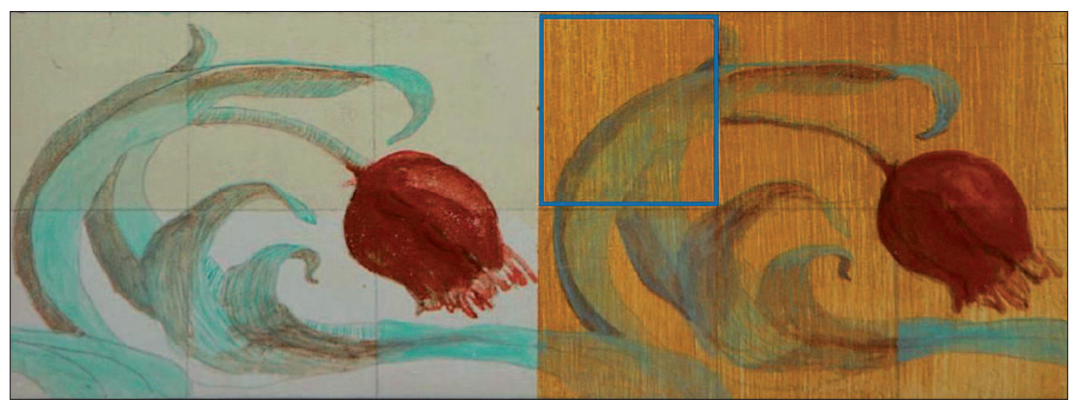

Il. 7. Tempera modyfikowana terpentyną wenecką na zaprawie kredowo-klejowej na podobraziu drewnianym. Każda z technik nakładania dała zadowalające efekty, jedynie na imprimaturze kazeinowej z izolacją olejno-żywiczną farba miejscowo perliła się utrudniając laserowanie (ramka)

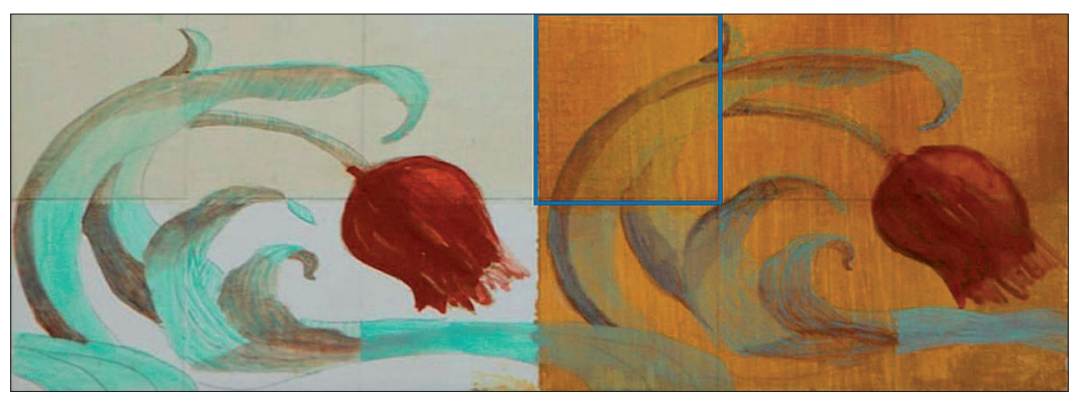

Il. 8. Tempera modyfikowana terpentyną wenecką na klejowej zaprawie kazeinowej w 5 warstwach na podobraziu drewnianym. Każda z technik nakładania dała zadowalające efekty, jedynie na imprimiturze kazeinowej z izolacją olejno-żywiczną uzyskano bardzo delikatne, słabo widoczne laserunki (ramka) 
Tab. 1. Zestawienie prób kredowej zaprawy kazeinowo-olejnej (emulsyjnej) z różną zawartością oleju lnianego i w różnej liczbie warstw (do dalszych prób wykorzystano zaprawę w wariancie $2-$ zaznaczony czerwona ramka).

\begin{tabular}{|c|c|c|c|c|c|c|c|c|}
\hline Liczba warstw & & Powys & hnięciu & & & Po $2 \mathrm{mi}$ & siącach & \\
\hline $\begin{array}{l}\text { Zawar- } \\
\text { tość oleju } \\
\text { w spoiwie zaprawy }\end{array}$ & $\begin{array}{c}1 \\
\text { warstwa }\end{array}$ & $\begin{array}{c}2 \\
\text { warstwy }\end{array}$ & $\begin{array}{c}3 \\
\text { warstwy }\end{array}$ & $\begin{array}{c}4 \\
\text { warstwy }\end{array}$ & $\begin{array}{c}1 \\
\text { warstwa }\end{array}$ & $\begin{array}{c}2 \\
\text { warstwy }\end{array}$ & $\begin{array}{c}3 \\
\text { warstwy }\end{array}$ & $\begin{array}{c}4 \\
\text { warstwy }\end{array}$ \\
\hline $\begin{array}{l}\text { I. } \quad \underline{5 \%}: \\
0,5 \text { cz. oleju }+9,5 \mathrm{cz} \\
\text { kleju kazeinowego }\end{array}$ & & & & & & & & \\
\hline $\begin{array}{l}\text { II. } \underline{10 \%} \text { : } \\
1 \text { cz. oleju + } 9 \text { cz. } \\
\text { kleju kazeinowego }\end{array}$ & & & & & & & & \\
\hline $\begin{array}{c}\text { III. } 20 \% \text { : } \\
2 \text { cz. oleju }+8 \mathrm{cz} . \\
\text { kleju kazeinowego }\end{array}$ & & & & & & & & \\
\hline $\begin{array}{c}\text { IV. } 30 \% \text { : } \\
3 \mathrm{cz.} \mathrm{oleju}+7 \mathrm{cz} . \\
\text { kleju kazeinowego }\end{array}$ & & & & & & & & \\
\hline $\begin{array}{c}\text { V. } \frac{40 \%}{4} \text { cz. oleju }+6 \mathrm{cz} . \\
\text { kleju kazeinowego }\end{array}$ & & & & & & & & \\
\hline
\end{tabular}


Tab. 2. Schemat malowania wyjaśniający sposób rozrysowania linii na podobraziach. Schemat nie określa rodzaju zaprawy, ponieważ była ona inna na każdym z podobrazi, co wyjaśnia il. 1. $\mathrm{Na}$ podobraziach 1 i 4 nie nałożono zaprawy, lecz pozostałe elementy zgodne są z powyższą tabela.

\begin{tabular}{|c|c|c|c|c|c|}
\hline $\begin{array}{c}\text { zaprawa, } \\
\text { izolacja, } \\
\text { podmalowanie i } \\
\text { laserunek } \\
\text { tempera } 1 \\
\end{array}$ & $\begin{array}{c}\text { zaprawa, } \\
\text { izolacja, } \\
\text { podmalowanie i } \\
\text { szrafowanie } \\
\text { tempera } 1 \\
\end{array}$ & \begin{tabular}{|c|} 
zaprawa, \\
izolacja, \\
podmalowanie, \\
malowanie kryjące \\
i impastowe \\
tempera 1 \\
\end{tabular} & $\begin{array}{c}\text { zaprawa, } \\
\text { imprimatura, } \\
\text { izolacja, } \\
\text { podmalowanie i } \\
\text { laserunek } \\
\text { tempera } 1 \\
\end{array}$ & $\begin{array}{c}\text { zaprawa, } \\
\text { imprimatura, } \\
\text { izolacja, } \\
\text { podmalowanie i } \\
\text { szrafowanie } \\
\text { tempera } 1\end{array}$ & $\begin{array}{c}\text { zaprawa, } \\
\text { imprimatura, } \\
\text { izolacja, } \\
\text { podmalowanie, } \\
\text { malowanie kryjące } \\
\text { i impastowe } \\
\text { tempera 1 } \\
\end{array}$ \\
\hline $\begin{array}{l}\text { zaprawa, } \\
\text { podmalowanie i } \\
\text { laserunek }\end{array}$ & $\begin{array}{c}\text { zaprawa, } \\
\text { podmalowanie i } \\
\text { szrafowanie } \\
\text { tempera } 1\end{array}$ & $\begin{array}{c}\text { zaprawa, } \\
\text { podmalowanie } \\
\text { malowanie kryjące } \\
\text { i impastowe } \\
\text { tempera } 1\end{array}$ & $\begin{array}{c}\text { zaprawa, } \\
\text { imprimatura, } \\
\text { podmalowanie i } \\
\text { laserunek } \\
\text { tempera } 1\end{array}$ & $\begin{array}{c}\text { zaprawa, } \\
\text { imprimatura, } \\
\text { podmalowanie } \\
\text { temperą 1, } \\
\text { szrafowanie } \\
\text { tempera } 1\end{array}$ & $\begin{array}{c}\text { zaprawa, } \\
\text { imprimatura, } \\
\text { podmalowanie, } \\
\text { malowanie kryjące } \\
\text { i impastowe } \\
\text { tempera } 1\end{array}$ \\
\hline $\begin{array}{c}\text { zaprawa, } \\
\text { izolacja, } \\
\text { podmalowanie i } \\
\text { laserunek } \\
\text { tempera } 2\end{array}$ & $\begin{array}{c}\text { zaprawa, } \\
\text { izolacja, } \\
\text { podmalowanie i } \\
\text { szrafowanie } \\
\text { tempera } 2 \\
\end{array}$ & \begin{tabular}{c|} 
zaprawa, \\
izolacja, \\
podmalowanie \\
malowanie kryjące \\
i impastowe \\
tempera 2 \\
\end{tabular} & $\begin{array}{c}\text { zaprawa, } \\
\text { imprimatura, } \\
\text { izolacja, } \\
\text { podmalowanie i } \\
\text { laserunek } \\
\text { tempera } 2 \\
\end{array}$ & $\begin{array}{c}\text { zaprawa, } \\
\text { imprimatura, } \\
\text { izolacja, } \\
\text { podmalowanie i } \\
\text { szrafowanie } \\
\text { tempera } 2 \\
\end{array}$ & $\begin{array}{c}\text { zaprawa, } \\
\text { imprimatura, } \\
\text { izolacja, } \\
\text { podmalowanie, } \\
\text { malowanie kryjące } \\
\text { i impastowe } \\
\text { tempera 2 } \\
\end{array}$ \\
\hline $\begin{array}{c}\text { zaprawa, } \\
\text { podmalowanie i } \\
\text { laserunek } \\
\text { tempera } 2\end{array}$ & $\begin{array}{c}\text { zaprawa, } \\
\text { podmalowanie i } \\
\text { szrafowanie } \\
\text { tempera } 2\end{array}$ & $\begin{array}{c}\text { zaprawa, } \\
\text { podmalowanie } \\
\text { malowanie kryjące } \\
\text { i impastowe } \\
\text { tempera } 2\end{array}$ & $\begin{array}{c}\text { zaprawa, } \\
\text { imprimatura, } \\
\text { podmalowanie } \\
\text { ilaserunek } \\
\text { tempera } 2\end{array}$ & $\begin{array}{c}\text { zaprawa, } \\
\text { imprimatura, } \\
\text { podmalowanie i } \\
\text { szrafowanie } \\
\text { tempera } 2\end{array}$ & $\begin{array}{c}\text { zaprawa, } \\
\text { imprimatura, } \\
\text { podmalowanie, } \\
\text { malowanie kryjące } \\
\text { i impastowe } \\
\text { tempera } 2\end{array}$ \\
\hline $\begin{array}{c}\text { zaprawa, } \\
\text { izolacja, } \\
\text { podmalowanie i } \\
\text { laserunek } \\
\text { tempera } 3\end{array}$ & $\begin{array}{c}\text { zaprawa, } \\
\text { izolacja, } \\
\text { podmalowanie i } \\
\text { szrafowanie } \\
\text { tempera } 3\end{array}$ & $\begin{array}{c}\text { zaprawa, } \\
\text { izolacja, } \\
\text { podmalowanie } \\
\text { malowanie kryjące } \\
\text { i impastowe } \\
\text { tempera } 3 \\
\end{array}$ & $\begin{array}{c}\text { zaprawa, } \\
\text { imprimatura, } \\
\text { izolacja, } \\
\text { podmalowanie i } \\
\text { laserunek }\end{array}$ & $\begin{array}{c}\text { zaprawa, } \\
\text { imprimatura, } \\
\text { izolacja, } \\
\text { podmalowanie i, } \\
\text { szrafowanie } \\
\text { tempera } 3\end{array}$ & $\begin{array}{c}\text { zaprawa, } \\
\text { imprimatura, } \\
\text { izolacja, } \\
\text { podmalowanie, } \\
\text { malowanie kryjące } \\
\text { i impastowe } \\
\text { tempera } 3\end{array}$ \\
\hline $\begin{array}{c}\text { zaprawa, } \\
\text { izolacja, } \\
\text { podmalowanie i } \\
\text { laserunek } \\
\text { tempera } 3\end{array}$ & $\begin{array}{c}\text { zaprawa, } \\
\text { izolacja, } \\
\text { podmalowanie i } \\
\text { szrafowanie } \\
\text { tempera } 3\end{array}$ & $\begin{array}{c}\text { zaprawa, } \\
\text { izolacja, } \\
\text { podmalowanie } \\
\text { malowanie kryjące } \\
\text { i impastowe } \\
\text { tempera } 3\end{array}$ & $\begin{array}{c}\text { zaprawa, } \\
\text { imprimatura, } \\
\text { izolacja, } \\
\text { podmalowanie i } \\
\text { laserunek } \\
\text { tempera } 3\end{array}$ & $\begin{array}{c}\text { zaprawa, } \\
\text { imprimatura, } \\
\text { izolacja, } \\
\text { podmalowanie i } \\
\text { szrafowanie } \\
\text { tempera } 3\end{array}$ & $\begin{array}{c}\text { zaprawa, } \\
\text { imprimatura, } \\
\text { izolacja, } \\
\text { podmalowanie, } \\
\text { malowanie kryjące } \\
\text { i impastowe } \\
\text { tempera } 3\end{array}$ \\
\hline $\begin{array}{c}\text { zaprawa, } \\
\text { izolacja, } \\
\text { podmalowanie i } \\
\text { laserunek } \\
\text { tempera } 4\end{array}$ & $\begin{array}{c}\text { zaprawa, } \\
\text { izolacja, } \\
\text { podmalowanie i } \\
\text { szrafowanie }\end{array}$ & $\begin{array}{c}\text { zaprawa, } \\
\text { izolacja, } \\
\text { podmalowanie } \\
\text { malowanie kryjące } \\
\text { i impastowe } \\
\text { tempera } 4 \\
\end{array}$ & $\begin{array}{c}\text { zaprawa, } \\
\text { imprimatura, } \\
\text { izolacja, } \\
\text { podmalowanie i } \\
\text { laserunek }\end{array}$ & $\begin{array}{c}\text { zaprawa, } \\
\text { imprimatura, } \\
\text { izolacja, } \\
\text { podmalowanie i } \\
\text { szrafowanie }\end{array}$ & $\begin{array}{c}\text { zaprawa, } \\
\text { imprimatura, } \\
\text { izolacja, } \\
\text { podmalowanie, } \\
\text { malowanie kryjące } \\
\text { i impastowe } \\
\text { tempera } 4\end{array}$ \\
\hline $\begin{array}{c}\text { zaprawa, } \\
\text { izolacja, } \\
\text { podmalowanie i } \\
\text { laserunek } \\
\text { tempera } 4\end{array}$ & $\begin{array}{c}\text { zaprawa, } \\
\text { izolacja, } \\
\text { podmalowanie i } \\
\text { szrafowanie }\end{array}$ & $\begin{array}{c}\text { zaprawa, } \\
\text { izolacja, } \\
\text { podmalowanie } \\
\text { malowanie kryjące } \\
\text { i impastowe } \\
\text { tempera } 4\end{array}$ & $\begin{array}{c}\text { zaprawa, } \\
\text { imprimatura, } \\
\text { izolacja, } \\
\text { podmalowanie i } \\
\text { laserunek }\end{array}$ & $\begin{array}{c}\text { zaprawa, } \\
\text { imprimatura, } \\
\text { izolacja, } \\
\text { podmalowanie i } \\
\text { szrafowanie }\end{array}$ & $\begin{array}{c}\text { zaprawa, } \\
\text { imprimatura, } \\
\text { izolacja, } \\
\text { podmalowanie, } \\
\text { malowanie kryjące } \\
\text { i impastowe } \\
\text { tempera } 4\end{array}$ \\
\hline
\end{tabular}


Tab. 3. Próba malarstwa impastowego tempera kazeinową

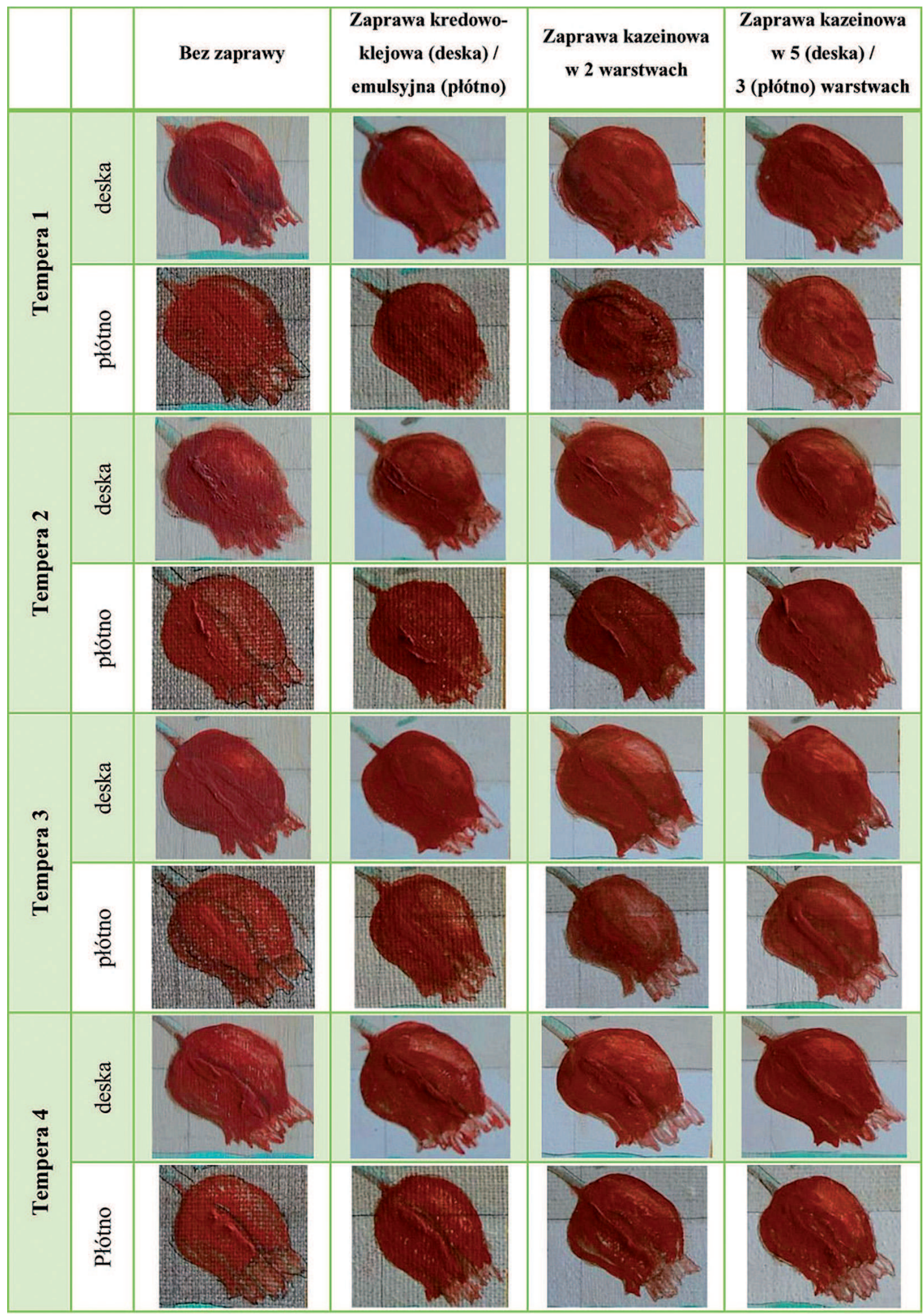

